\title{
Epidemiological Profile of the Victims of Sexual Violence Treated at a Referral Center in Southern Brazil
}

\section{Perfil epidemiológico das vítimas de violência sexual atendidas em um centro de referência do Sul do Brasil}

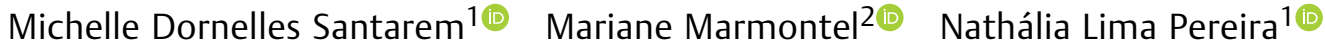 \\ Letícia Becker Vieira $^{1+}$ Ricardo Francalacci Savaris ${ }^{30}$
}

${ }^{1}$ Department of Medical-Surgical Nursing, Escola de Enfermagem, Universidade Federal do Rio Grande do Sul, Porto Alegre, RS, Brasil

${ }^{2}$ Hospital de Clínicas de Porto Alegre, Porto Alegre, RS, Brasil

${ }^{3}$ Department of Gynecology and Obstetrics, Faculdade de Medicina, Universidade Federal do Rio Grande do Sul, Porto Alegre, RS, Brasil

Address for correspondence Ricardo Francalacci Savaris, MD, MSc, PhD, Faculdade de Medicina, Universidade Federal do Rio Grande do Sul, Porto Alegre, RS, Brasil (e-mail: rsavaris@hcpa.edu.br).

Rev Bras Ginecol Obstet 2020;42(9):547-554.

\begin{abstract}
Keywords

- women's health service

- violence against women

- sexual violence

- rape
\end{abstract}

Resumo
Objective To characterize the sociodemographic profile of women victims of sexual violence treated at a university hospital in southern Brazil.

Method The present cross-sectional study included all female victims of sexual violence who attended the sexual violence unit at the Hospital de Clínicas de Porto Alegre (HCPA, in the Portuguese acronym) from April 18, 2000 to December 31, 2017. Data were extracted from the electronic record of the patients and stored in a standardized questionnaire database with epidemiological aspects of the victim, the perpetrators and the type of aggression. Statistical analysis was performed using the chi-squared test for trend and descriptive statistics with 95\% confidence interval (Cl). Results During the length of the study, 711 women victims of sexual violence were treated. The mean age of the patients was $24.4( \pm 10)$ years old (range from 11 to 69 years old) and most of the victims were white $(77.4 \%)$, single $(75.9 \%)$ and sought care at the unit within 72 hours after the occurrence (80.7\%). In most cases, violence was exerted by a single perpetrator ( $87.1 \%$ ), who was unknown in $67.2 \%$ of cases. Victims $<19$ years old showed a higher risk of not using contraception (relative risk $[\mathrm{RR}]=2.7 ; 95 \% \mathrm{Cl}=1.9-3.6)$.

Conclusion Most victims of sexual violence were treated within 72 hours of the occurrence. The majority of these victims were white and young, and those $<19$ years old had a higher risk of not using contraception and to know the sexual perpetrator.

Objetivo Caracterizar o perfil sociodemográfico de mulheres vítimas de violência sexual atendidas em um hospital universitário da região Sul do Brasil.

Métodos Estudo transversal de todas as mulheres atendidas na unidade de vítimas de violência sexual do Hospital de Clínicas de Porto Alegre (HCPA) entre 18 de abril de received

March 7, 2019

accepted

June 30,2020
DOI https://doi.org/

10.1055/s-0040-1715577. ISSN 0100-7203.
Copyright $\odot 2020$ by Thieme Revinter

Publicações Ltda, Rio de Janeiro, Brazil
License terms

(c) (i) 
Palavras-chave

- serviço de saúde da mulher

- violência contra a mulher

- violência sexual

- delitos sexuais

- estupro
2000 a 31 de dezembro de 2017. Os dados foram extraídos a partir do registro eletrônico de um questionário padronizado envolvendo aspectos epidemiológicos da vítima, do agressor e do tipo de agressão. O teste qui-quadrado foi empregado para tendência e estatística descritiva com $95 \%$ de intervalo de confiança (IC) foram utilizados para análise estatística.

Resultados Foram atendidas 711 mulheres vítimas de violência sexual. A média da idade das pacientes foi de $24,4( \pm 10)$ anos, sendo que a maioria das vítimas era branca $(77,4 \%)$, solteira $(75,9 \%)$ e buscou atendimento na unidade dentro de 72 horas após a ocorrência (80,7\%). Na maioria dos casos, a violência foi exercida por agressor único $(87,1 \%)$, sendo este desconhecido em $67,2 \%$ dos casos. As vítimas $<19$ anos mostraram um maior risco de não estarem usando algum método contraceptivo (risco relativo $[R R]=2,7 ; \mathrm{IC} 95 \%=1,9-3,6)$.

Conclusão A maioria das vítimas de violência sexual foi atendida dentro de 72 horas da ocorrência. As vítimas sexuais eram, na sua maioria, brancas e jovens, sendo que as $<19$ anos apresentavam um maior risco de não estarem utilizando algum método contraceptivo e de conhecerem o seu agressor.

\section{Introduction}

Violence against women is defined as "any act based on gender that causes death, harm or physical, sexual or psychological distress to women, whether in the public or the private sphere," or as "any sexual act, attempt to obtain a sexual act, unwanted sexual comments or advances, or acts to traffic, or otherwise directed, against a person's sexuality using coercion, by any person, regardless of their relationship to the victim, in any setting, including but not limited to home and work." 1,2 This type of violence has been a public health problem. Sexual violence can expose the victims to sexually transmitted infections, to unwanted pregnancy and to emotional problems in the short or long term, for instance, suicide and depression. ${ }^{3}$ Twenty to $60 \%$ of the victims do not tell anyone or do not seek institutional help to report intimate partner violence. ${ }^{4}$ The lack of official data and the underreporting problem are challenging for researchers in this area. ${ }^{5}$ Data from specialized centers for the care of women victims of sexual abuse are scarce. ${ }^{6}$

Homicide rates against women in Brazil have been steadily increasing since 2007, reaching 4.8 cases of female homicides/ 100,000 inhabitants in 2013. ${ }^{7}$ Data from the informatics department of the Brazilian Unified Health System (DATASUS), the official electronic database of the Brazilian Ministry of Health, revealed that 243,259 domestic, sexual and/or other violence were registered in Brazil in 2016, of which 22,648 rapes were reported. ${ }^{8}$ Around 21.9 women seek health care services for sexual violence every day and there are 14.2 reports of women victims of rape daily. ${ }^{9}$

A study revealed that the number of police reports against women in the state of Rio Grande do Sul, Brazil, more specifically in the cities of Santa Maria, Erechim and Santana do Livramento, ranged from 66 to 361 cases between 2005 and $2009 .^{10}$ This variability in the number of police reports may be due to the systematic lack of data collection in a specialized unit for this activity. The gynecological emergency unit (GEU) of the Hospital de Clínicas de Porto Alegre (HCPA, in the Portuguese acronym) has been a reference center for the care of women victims of sexual violence since April 2000. This unit offers multidisciplinary care in emergency and outpatient settings. The staff of this unit comprises gynecologists, psychiatrists, nurses, psychologists, and social workers. The consultation for this type of victim is aimed at the prevention of sexually transmitted infections (STIs) and unwanted pregnancy. This first emergency contact is a great opportunity to offer emergency contraception for those who need it. ${ }^{11}$ The GEU follows the Brazilian Ministry of Health protocols in this area and collects data from these victims in a systematic manner. ${ }^{12}$ This systematic data collection may reveal some aspects of this population and the conditions in which sexual violence had occurred. The objective of the present study is to characterize the socioepidemiological profile of these victims of sexual violence who were treated at the HCPA, a university hospital in the southern region of Brazil. As a secondary objective, the average age was compared between women who were or were not using contraception at the time of violence.

\section{Methods}

\section{Study Design and Setting}

This is a cross-sectional study, conducted from April 1, 2000 to December 31, 2017, at the Gynecological Emergency Unit at the Hospital de Clínicas de Porto Alegre (GEU-HCPA, in the Portuguese acronym), Porto Alegre, Rio Grande do Sul, Brazil.

\section{Participants}

Women victims of sexual assault, aged $\geq 10$ years old, who were referred to or came spontaneously to the GEU, and had an electronic medical record were included in the study. Those without electronic records and male victims were excluded. 


\section{Variables}

Age (in years), ethnicity (by self-declaration), marital status, years of education, profession, characterization of sexual violence, that is, place where the violence occurred, number of perpetrators, characteristics of the perpetrator, whether or not there was a previous relationship between the perpetrator and the victim, form of intimidation, type of sexual assault, occurrence or not of ejaculation, first or repeated aggression, use of contraceptive method at the time of the violence, existence or not of police report and presumed age of the perpetrator were evaluated as study variables. The time elapsed between the sexual assault and the medical care and whether exams, prophylaxis, referrals for hepatitis $B$ vaccination were provided or not were also evaluated.

\section{Data Sources/Measurements}

After direct interviews with the patient, data were entered into an electronic medical record. Data from the electronic medical records of the patients were obtained and transferred to a specific database developed for this purpose (GoogleForms, Google LLC, Mountain View, CA, USA). Data was collected for a period of 215 months. A training period of 3 months was performed to assure the consistency of the database input. No strategy for statistical analysis was applied for missing values.

\section{Bias}

Data were entered independently by two researchers (Marmontel M. and Santarem M. D.), which were later compared for reducing bias. Discrepancies were solved by reviewing the electronic medical record by a senior professional (Savaris R. F.) or reinterviewing the patient. Reinterview of the patient was performed either in the follow-up consultation, or by telephone by one of the authors (Marmontel M.), responsible for the outpatient clinic. In case of outdated telephone numbers, the social service of the hospital was activated.

\section{Sample Size}

The sample was for convenience and included all cases treated within 18 years.

\section{Quantitative Variables}

Quantitative variables were described as means and standard deviations (SD). The population was divided into 2 groups based on a cutoff of the age most likely of not using any contraceptive method.

\section{Statistical Methods}

Statistical analysis was descriptive using percentage and 95\% confidence interval $(\mathrm{CI})$, mean with SD. The identification of a

Table 1 Sociodemographic characteristics of women victims of sexual violence

\begin{tabular}{|c|c|c|c|c|c|c|c|}
\hline \multirow[t]{2}{*}{ Variable } & \multicolumn{2}{|c|}{ Overall $(n=711)$} & \multicolumn{2}{|c|}{$\leq 19$ years old $(n=262)$} & \multicolumn{2}{|c|}{$>19$ years old $(n=449)$} & \multirow[t]{2}{*}{ p-value } \\
\hline & $\mathrm{n}(\%)$ & $95 \% \mathrm{Cl}$ & n (\%) & $95 \% \mathrm{Cl}$ & n (\%) & $95 \% \mathrm{Cl}$ & \\
\hline \multicolumn{8}{|l|}{ Ethnic group } \\
\hline White & $550(77.4)$ & $74.1-80.3$ & $194(74)$ & $68.4-79.0$ & $356(79.3)$ & $75.3-82.8$ & 0.08 \\
\hline Non-white & $154(21.6)$ & $18.8-24.8$ & $64(24.4)$ & $19.6-3.0$ & $90(20)$ & $16.6-24.0$ & \\
\hline Ignored & $7(1.0)$ & $0.5-2.1$ & $4(1.5)$ & $0.6-4.0$ & $3(2.1)$ & $0.2-2.1$ & \\
\hline \multicolumn{8}{|l|}{ Marital Status } \\
\hline Single & $540(75.9)$ & $72.7-79.0$ & $248(94.7)$ & $91.2-96.8$ & $292(65.0)$ & $60.5-69.3$ & $<0.001$ \\
\hline Married & $100(14.1)$ & $11.7-16.8$ & $7(2.7)$ & $1.3-5.5$ & $93(20.7)$ & $17.2-24.7$ & \\
\hline Separated or Widow & $64(9.0)$ & $7.1-11.3$ & $1(0.4)$ & $0.1-2.7$ & $63(14)$ & $11.1-17.6$ & \\
\hline Ignored & $7(1.0)$ & $0.5-2.1$ & $6(2.3)$ & $1.0-5.0$ & $1(0.2)$ & $0-1.6$ & \\
\hline \multicolumn{8}{|l|}{ Education } \\
\hline Illiterate & $9(1.3)$ & $0.7-2.4$ & $2(0.8)$ & $0.2-3.0$ & $7(1.6)$ & $0.7-3.2$ & $<0.001$ \\
\hline$\leq 9$ years & $256(36.0)$ & $32.5-39.6$ & $137(52.3)$ & $46.2-58.3$ & $119(26.5)$ & $22.6-30.8$ & \\
\hline $10-12$ years & $299(42.1)$ & $38.5-45.7$ & $96(36.6)$ & $31.0-36.6$ & $203(45.2)$ & $40.7-49.9$ & \\
\hline$\geq 13$ years & $87(12.2)$ & $10.0-14.9$ & $2(0.8)$ & $0.2-3.0$ & 85 (18.9) & $22.8-15.6$ & \\
\hline Ignored & $60(8.4)$ & $6.6-10.7$ & $25(9.5)$ & $6.5-13.8$ & $35(7.8)$ & $5.6-10.7$ & \\
\hline \multicolumn{8}{|l|}{ Employment status } \\
\hline Unemployed & $71(10)$ & $8.0-12.4$ & $12(4.6)$ & $2.6-7.8$ & $59(13.1)$ & $10.3-16.6$ & $<0.001$ \\
\hline Employed & $223(31.4)$ & $28.1-34.9$ & $22(8.4)$ & $5.6-12.4$ & $201(44.8)$ & $40.2-49.4$ & \\
\hline Student & $218(30.7)$ & $27.4-34.2$ & $154(58.8)$ & $52.7-64.6$ & $64(14.3)$ & $11.3-17.8$ & \\
\hline Ignored & 199 (28.0) & $24.8-31.4$ & $74(28.2)$ & $23.1-34.0$ & $125(27.8)$ & $23.9-32.2$ & \\
\hline
\end{tabular}

Abbreviation: $\mathrm{Cl}$, confidence interval.

${ }^{*}$ Chi-squared for trend comparing groups $\leq 19$ and $>19$ years old only. 
cutoff of age as the most likely of not using any contraceptive method was verified by the curve receiver operator characteristics (ROC). After identifying this cutoff, the sample was divided into 2 groups for further comparisons, using the chisquared test for trend or the Mann Whitney test. Statistical analyses were performed using the Prism 8 software (GraphPad Software, San Diego, California, USA).

\section{Ethical Aspects}

The present study was submitted and approved by the Research Ethics Committee of the HCPA (CAAE = 84939318000005327).

\section{Results}

\section{Participants}

Between April 18, 2000 and December 31, 2017, a total of 711 female victims of sexual violence (100\%) were screened for consultation and entered in the analysis. There were no exclusions.

\section{Descriptive Data}

The mean (SD) and median age of the studied population were $24.1( \pm 10)$ years old and 22 years old, respectively, ranging from 11 to 69 years old. Further details of the population characteristics, the characteristics of violence and the provided care given at the first visit are described in -Tables 1, 2 and 3, respectively.

\section{Outcome Data}

The median age of the victims using contraception $(n=215)$ was significantly higher compared with those not using any method $(n=496)$ (24 versus 20; $p<0.0001$; Mann Whitney test). In the ROC curve analysis ( - Fig. 1 ), the cutoff point for identifying women with a higher risk of not using contraception was 19 years old. From a total of 262 women $\leq 19$ years old, only 61 were using some contraceptive method, (23.3\%; 95\%CI: 18.6-28.8\%). In contrast, 449 women were $>19$ years old; from these, 173 were using some contraceptive method (38.5\%; 95\%CI: 34.0-43.2\%). These figures give a relative risk $(\mathrm{RR})=2.7(95 \% \mathrm{CI}=1.96-3.6)$.

\section{Main Results|Other Analyzes}

The subgroup analysis of the population revealed that most of the perpetrators were known by the victims $\leq 19$ years old and the vaginal contact was more common in this subgroup, while those $>19$ years old suffered more than one sexual contact and the majority of the women $>19$ years old were married or with a previous relationship (-Table 1). Women $\leq 19$ years old received more emergency contraception (69.1\%; $95 \% \mathrm{CI}=63.2-74.4 \%)$. Most victims of violence sought

Table 2 Characteristics of the sexual violence in the studied population and by the age of 19 years old

\begin{tabular}{|c|c|c|c|c|c|c|c|}
\hline \multirow[t]{2}{*}{ Variable } & \multicolumn{2}{|c|}{ Overall $(n=711)$} & \multicolumn{2}{|c|}{$\leq 19$ years old $(n=262)$} & \multicolumn{2}{|c|}{$>19$ years old $(n=449)$} & \multirow[t]{2}{*}{ p-value* } \\
\hline & $\mathrm{n}(\%)$ & $95 \% \mathrm{Cl}$ & $\mathrm{n}(\%)$ & $95 \% \mathrm{Cl}$ & n (\%) & $95 \% \mathrm{Cl}$ & \\
\hline \multicolumn{8}{|l|}{ First occurrence } \\
\hline Yes & $525(73.8)$ & $70.5-76.9$ & $201(76.7)$ & $71.2-81.5$ & $324(72.2)$ & $67.8-76.1$ & \\
\hline No & $37(5.2)$ & $3.8-7.1$ & $16(6.1)$ & $3.8-9.7$ & $21(4.7)$ & $3.1-7.1$ & 0.1 \\
\hline Ignored & $149(21.0)$ & $18.1-24.1$ & $45(17.2)$ & $13.1-22.2$ & $104(23.2)$ & $19.5-27.3$ & \\
\hline \multicolumn{8}{|c|}{ Relationship with perpetrators } \\
\hline Unknown & $478(67.2)$ & $63.7-70.6$ & $152(58.0)$ & $51.9-63.9$ & $326(72.6)$ & $68.3-76.5$ & \\
\hline Known & $207(29.1)$ & $25.9-32.6$ & $99(37.8)$ & $32.1-43.8$ & $108(24.1)$ & $20.3-28.2$ & $<0.001$ \\
\hline Ignored & $26(3.7)$ & $2.5-5.3$ & $11(4.2)$ & $2.3-7.4$ & $15(3.3)$ & $2.0-5.5$ & \\
\hline \multicolumn{8}{|l|}{ Place of occurrence } \\
\hline Street & $87(12.2)$ & $10.0-14.9$ & $27(10.3)$ & $7.2-14.6$ & $60(13.4)$ & $10.5-16.8$ & \\
\hline Residence & $166(23.3)$ & $20.4-26.6$ & $67(25.6)$ & $20.6-31.2$ & $99(22.0)$ & $18.4-26.1$ & \\
\hline Work & $19(2.7)$ & $1.7-4.2$ & $2(0.8)$ & $0.2-3.0$ & $17(3.8)$ & $2.4-6.0$ & 0.4 \\
\hline Other & $44(6.2)$ & $4.6-8.2$ & $13(5.0)$ & $2.9-8.4$ & 31 (6.9) & $4.9-9.7$ & \\
\hline Ignored & $395(55.6)$ & $51.9-59.2$ & $153(58.4)$ & $52.3-64.2$ & 242 (53.9) & $49.3-58.5$ & \\
\hline \multicolumn{8}{|l|}{ Number of perpetrators } \\
\hline Single & $619(87.1)$ & $84.4-89.3$ & $232(88.5)$ & $84.1-91.9$ & $387(86.2)$ & $82.7-89.1$ & \\
\hline Multiple & $73(10.3)$ & $8.2-12.7$ & $20(7.6)$ & $5.0-11.5$ & $53(11.8)$ & $9.1-15.1$ & 0.8 \\
\hline Ignored & $19(2.7)$ & $1.7-4.2$ & $10(3.8)$ & $2.7-7.0$ & $9(2.0)$ & $1.0-3.8$ & \\
\hline \multicolumn{8}{|l|}{ Form of Aggression } \\
\hline Physical & 139 (19.5) & $16.8-22.6$ & $44(16.8)$ & $12.7-21.8$ & $95(21.2)$ & $17.6-25.2$ & \\
\hline Verbal & $48(6.8)$ & $5.1-8.9$ & $15(5.7)$ & $3.5-9.3$ & $33(7.3)$ & $5.3-10.2$ & 0.3 \\
\hline More than one type & $16(2.3)$ & $1.4-3.6$ & $4(1.5)$ & $0.6-4.0$ & $12(2.7)$ & $1.5-4.7$ & \\
\hline Ignored & $508(71.4)$ & $68.0-74.7$ & $199(76.0)$ & $7.4-80.8$ & $309(68.8)$ & $64.4-72.9$ & \\
\hline
\end{tabular}


Table 2 (Continued)

\begin{tabular}{|c|c|c|c|c|c|c|c|}
\hline \multirow[t]{2}{*}{ Variable } & \multicolumn{2}{|c|}{ Overall $(n=711)$} & \multicolumn{2}{|c|}{$\leq 19$ years old $(n=262)$} & \multicolumn{2}{|c|}{$>19$ years old $(n=449)$} & \multirow[t]{2}{*}{$p$-value } \\
\hline & $\mathrm{n}(\%)$ & $95 \% \mathrm{Cl}$ & n (\%) & $95 \% \mathrm{Cl}$ & n (\%) & $95 \% \mathrm{Cl}$ & \\
\hline \multicolumn{8}{|l|}{ Type sexual contact } \\
\hline Oral & $15(2.1)$ & $1.3-3.5$ & $6(2.3)$ & $1.0-5.0$ & $9(2.0)$ & $1.0-3.8$ & \\
\hline Anal & $22(3.1)$ & $2.0-4.7$ & $9(3.4)$ & $1.8-6.5$ & $13(2.9)$ & $1.7-4.9$ & \\
\hline Vaginal & $366(51.5)$ & $47.8-55.1$ & $155(59.2)$ & $53.1-65.0$ & $211(47.0)$ & $42.4-51.6$ & 0.01 \\
\hline More than one type & $244(34.3)$ & $30.9-37.9$ & $70(26.7)$ & $21.7-32.4$ & $174(38.8)$ & $34.3-43.4$ & \\
\hline Ignored & $64(9.0)$ & $7.1-11.3$ & $22(8.4)$ & $5.6-12.4$ & $42(9.4)$ & $7.0-12.4$ & \\
\hline \multicolumn{8}{|l|}{ Ejaculation } \\
\hline Yes & $344(48.4)$ & $44.7-52.1$ & $121(46.2)$ & $40.2-52.3$ & $223(49.7)$ & $45.0-54.3$ & \\
\hline No & $25(3.5)$ & $2.4-5.2$ & $7(2.7)$ & $1.3-5.5$ & $18(4.0)$ & $2.5-6.3$ & 0.2 \\
\hline Ignored & $342(48.1)$ & $44.4-51.8$ & $134(51.1)$ & $45.1-57.2$ & $208(46.3)$ & $41.7-51.0$ & \\
\hline \multicolumn{8}{|c|}{ Approximate age of the perpetrators } \\
\hline$\leq 20$ years old & $21(3.0)$ & $1.9-4.5$ & $5(1.9)$ & $0.8-4.5$ & $16(3.6)$ & $2.2-5.7$ & \\
\hline $21-30$ years old & $79(11.1)$ & $9.0-13.6$ & $28(10.7)$ & $7.5-15.1$ & $51(11.4)$ & $8.7-14.6$ & \\
\hline $31-40$ years old & $40(5.6)$ & $4.2-7.6$ & $11(4.2)$ & $2.3-7.4$ & $29(6.5)$ & $4.5-9.1$ & \\
\hline $41-60$ years old & $18(2.5)$ & $1.6-4.0$ & $9(3.4)$ & $1.8-6.5$ & $9(2.0)$ & $1.0-3.8$ & 0.2 \\
\hline Ignored & $553(77.8)$ & $74.6-80.7$ & $209(79.8)$ & $74.5-84.2$ & $344(76.6)$ & $72.5-80.3$ & \\
\hline \multicolumn{8}{|l|}{ Police Report } \\
\hline No & $39(5.5)$ & $4.0-7.4$ & $13(5.0)$ & $2.9-8.4$ & $26(5.8)$ & $4.0-8.4$ & \\
\hline Yes & $515(72.4)$ & $69.0-75.6$ & $203(77.5)$ & $72.0-82.1$ & $312(69.5)$ & $65.1-73.6$ & 0.1 \\
\hline Ignored & $157(22.1)$ & $19.2-25.3$ & $46(17.6)$ & $13.4-22.7$ & $111(24.7)$ & $20.9-28.9$ & \\
\hline
\end{tabular}

Abbreviation: $\mathrm{Cl}$, confidence interval.

${ }^{*}$ Chi-squared for trend comparing groups $\leq 19$ and $>19$ years old only.

Table 3 Description of emergency care given to the women after sexual violence

\begin{tabular}{|c|c|c|c|c|c|c|c|}
\hline \multirow[t]{2}{*}{ Variable } & \multicolumn{2}{|c|}{ Overall $(n=711)$} & \multicolumn{2}{|c|}{$\leq 19$ years old $(n=262)$} & \multicolumn{2}{|c|}{$>19$ years old $(n=449)$} & \multirow[t]{2}{*}{ p-value } \\
\hline & n (\%) & $95 \% \mathrm{Cl}$ & $\mathrm{n}(\%)$ & $95 \% \mathrm{Cl}$ & n (\%) & $95 \% \mathrm{Cl}$ & \\
\hline \multicolumn{8}{|c|}{ Presence of physical injuries } \\
\hline Yes & $13(1.8)$ & $1.1-3.1$ & $5(1.9)$ & $0.8-4.5$ & $8(1.8)$ & $0.9-3.5$ & \\
\hline No & $527(74.1)$ & $70.8-77.2$ & $187(71.4)$ & $65.6-76.5$ & $340(75.7)$ & $71.5-79.5$ & 0.2 \\
\hline Ignored & $171(24.1)$ & $21.0-27.3$ & $70(26.7)$ & $21.7-32.4$ & $101(22.5)$ & $18.9-26.6$ & \\
\hline \multicolumn{8}{|c|}{ Prophylaxis for sexually transmitted diseases dispensed } \\
\hline Yes & $612(86.1)$ & $83.3-88.4$ & $232(88.5)$ & $84.1-91.9$ & $380(84.6)$ & $87.7-81.0$ & \\
\hline No & $10(1.4)$ & $0.8-2.6$ & $4(1.5)$ & $0.6-4.0$ & $6(1.3)$ & $0.6-2.9$ & 0.1 \\
\hline Ignored & 89 (12.5) & $10.3-15.2$ & $26(9.9)$ & $6.8-14.2$ & $63(14.0)$ & $11.1-17.6$ & \\
\hline \multicolumn{8}{|c|}{ Prophylaxis for HIV dispensed } \\
\hline Yes & $621(87.3)$ & $84.7-89.6$ & $231(88.2)$ & $83.7-91.6$ & $390(86.9)$ & $83.4-89.7$ & \\
\hline No & $40(5.4)$ & $4.2-7.6$ & $15(5.7)$ & $3.5-9.3$ & $25(5.6)$ & $3.8-8.1$ & 0.5 \\
\hline Ignored & $50(7.0)$ & $5.4-9.2$ & $16(6.1)$ & $3.8-9.7$ & $34(7.6)$ & $5.5-10.4$ & \\
\hline \multicolumn{8}{|c|}{ Referral for Hepatitis B Vaccine } \\
\hline Yes & $609(85.7)$ & $82.9-88$ & $227(86.6)$ & $81.9-90.3$ & $382(85.1)$ & $81.5-88.1$ & \\
\hline No & $52(7.3)$ & $5.6-9.5$ & $19(7.3)$ & $4.7-11.1$ & $33(7.3)$ & $5.3-10.2$ & 0.4 \\
\hline Ignored & $50(7.0)$ & $5.4-9.2$ & $16(6.1)$ & $3.8-9.7$ & $34(7.6)$ & $5.5-10.4$ & \\
\hline \multicolumn{8}{|c|}{ Immunoglobulin Hepatitis B dispensed } \\
\hline Yes & $116(16.3)$ & $13.8-19.2$ & $49(18.7)$ & $14.4-23.9$ & $67(14.9)$ & $11.9-18.5$ & \\
\hline No & $545(76.7)$ & $73.4-79.6$ & $197(75.2)$ & $69.6-80.1$ & $348(77.5)$ & $73.4-81.1$ & 0.1 \\
\hline
\end{tabular}


552 Epidemiological Profile of the Victims of Sexual Violence Santarem et al.

Table 3 (Continued)

\begin{tabular}{|c|c|c|c|c|c|c|c|}
\hline \multirow[t]{2}{*}{ Variable } & \multicolumn{2}{|c|}{ Overall $(n=711)$} & \multicolumn{2}{|c|}{$\leq 19$ years old $(n=262)$} & \multicolumn{2}{|c|}{$>19$ years old $(n=449)$} & \multirow[t]{2}{*}{ p-value* } \\
\hline & $\mathrm{n}(\%)$ & $95 \% \mathrm{Cl}$ & $\mathrm{n}(\%)$ & $95 \% \mathrm{Cl}$ & n (\%) & $95 \% \mathrm{Cl}$ & \\
\hline Ignored & $50(7.0)$ & $5.4-9.2$ & $16(6.1)$ & $3.8-9.7$ & $34(7.6)$ & $5.5-10.4$ & \\
\hline \multicolumn{8}{|c|}{ Emergency contraception dispensed } \\
\hline Yes & $389(54.7)$ & $51.0-58.3$ & $181(69.1)$ & $63.2-74.4$ & $208(46.3)$ & $41.7-51.0$ & \\
\hline No & $272(38.3)$ & $34.7-41.9$ & $65(24.8)$ & $19.9-30.4$ & $207(46.1)$ & $41.5-50.7$ & $<0.001$ \\
\hline Ignored & $50(7.0)$ & $5.4-9.2$ & $16(6.1)$ & $3.8-9.7$ & $34(7.6)$ & $5.5-10.4$ & \\
\hline \multicolumn{8}{|c|}{ Victim was pregnant } \\
\hline Yes & $13(1.8)$ & $1.1-3.1$ & $2(0.8)$ & $0.2-3.0$ & $11(2.4)$ & $1.4-4.4$ & \\
\hline No & $454(63.9)$ & $60.2-67.3$ & $162(61.8)$ & $55.8-67.5$ & $292(65.0)$ & $60.5-69.3$ & 0.09 \\
\hline Ignored & $244(34.3)$ & $30.9-37.9$ & $98(37.4)$ & $31.7-43.4$ & $146(32.5)$ & $28.3-37.0$ & \\
\hline \multicolumn{8}{|c|}{ Sought consultation within $72 \mathrm{~h}$ of the violence } \\
\hline Yes & $574(80.7)$ & $77.7-83.5$ & $214(81.7)$ & $76.5-85.9$ & $360(80.2)$ & $76.2-83.6$ & \\
\hline No & $117(16.5)$ & $13.9-19.4$ & $41(15.6)$ & 11.7-20.6 & $76(16.9)$ & $13.7-20.7$ & 0.6 \\
\hline Ignored & $20(2.8)$ & $1.8-4.3$ & $7(2.7)$ & $1.3-5.5$ & $13(2.9)$ & $1.7-4.9$ & \\
\hline \multicolumn{8}{|c|}{ Referral to psychiatrist } \\
\hline Yes & $259(36.4)$ & $33.0-40.0$ & $93(35.5)$ & $29.9-41.5$ & $166(37.0)$ & $32.6-41.5$ & \\
\hline No & $272(38.3)$ & $34.7-41.9$ & $96(36.6)$ & $31.0-42.7$ & $176(39.2)$ & $34.8-43.8$ & 0.3 \\
\hline Ignored & $180(25.3)$ & $22.2-28.7$ & $73(27.9)$ & $22.8-33.6$ & $107(23.8)$ & $20.1-28.0$ & \\
\hline \multicolumn{8}{|c|}{ Follow-up at the gynecology outpatient clinic } \\
\hline Yes & $497(69.9)$ & $66.4-73.2$ & $181(69.1)$ & $63.2-74.4$ & $316(70.4)$ & $66.0-74.4$ & \\
\hline No & $208(29.3)$ & $26.0-32.7$ & $78(29.8)$ & $24.5-35.6$ & $130(29.0)$ & $24.9-33.3$ & 0.6 \\
\hline Ignored & $6(0.8)$ & $0.4-1.9$ & $3(1.1)$ & $0.4-3.5$ & $3(0.7)$ & $0.2-2.1$ & \\
\hline
\end{tabular}

Abbreviation: $\mathrm{Cl}$, confidence interval.

${ }^{*}$ Chi-squared for trend comparing groups $\leq 19$ and $>19$ years old only.

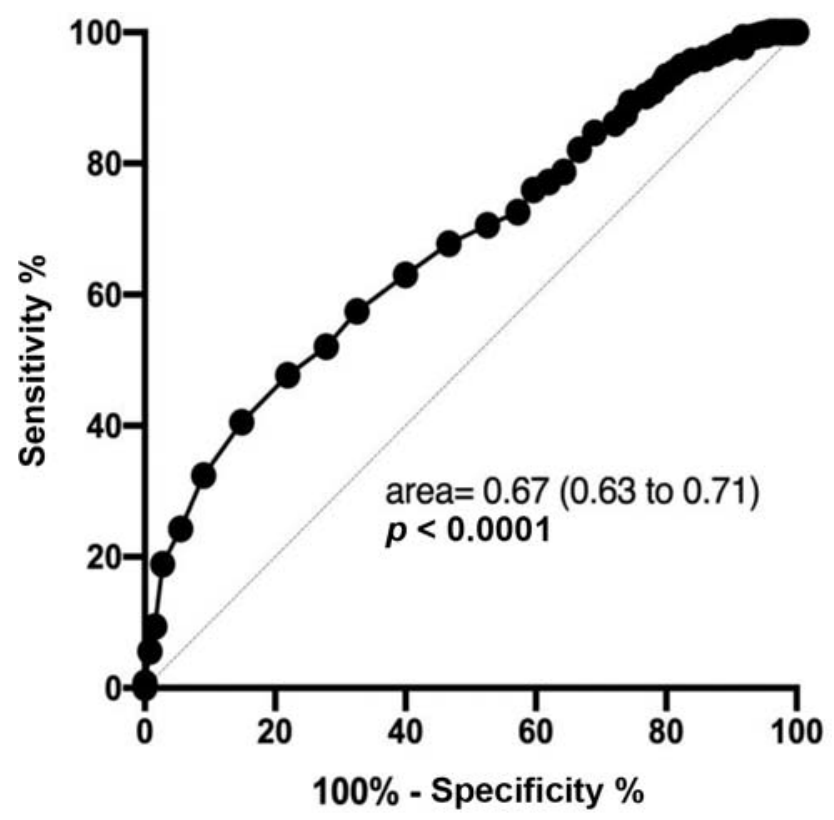

Fig. 1 ROC curve plotting age and use or not of any contraceptive method during the occurrence of sexual violence.

care within 72 hours of occurrence (574 out of 711 cases, 80.7\%; $95 \% \mathrm{CI}=77.7-83.5 \%$ ) and continued follow-up (497 out of 711 [69.9\%]; $95 \% \mathrm{CI}=66.4-73.2 \%$ ) at the gynecology outpatient clinic.

\section{Discussion}

The victims of sexual violence treated at the HCPA between 2000 and 2017 had a mean age of 24.4 years old. Those between 18 and 25 years old comprised $25.7 \%$ of the studied population ( 183 out of $711 ; 25.7 \% ; 95 \% \mathrm{CI}=22.7-29.1 \%$ ). Our data are different from the British data. Data from a referral center for sexual abuse cases in the UK showed that 50\% (95\% $\mathrm{CI}=46.9-53.6 \%)$ of the cases were aged between 18 and 25 years old. ${ }^{13}$ Our results also differ from those reported in DATASUS for 2017, either for Brazil (36.5\%) or for the state of Rio Grande do Sul (32.5\%). This discrepancy could be explained by the age distribution in the city of Porto Alegre, where $13 \%$ of the female population is between 15 and 29 years old. ${ }^{14}$

The main ethnic group in our cohort was white $(77.4 \%$; $95 \% \mathrm{CI}=74.1-80.3 \%$ ). This finding follows the DATASUS (2017) data; the majority of victims of violence in the state of Rio Grande do Sul are white (78.4\%; 16,962 out of 21,639). ${ }^{15}$ This is explained by the epidemiological profile of women from our state; from a universe of 5.4 million women, $83.2 \%$ are white. ${ }^{16}$ 
From our data, it was possible to verify that only $31.1 \%$ ( 221 of $711 ; 95 \% \mathrm{CI}=27.7 \%-34.6 \%$ ) of the victims of violence were using some contraceptive method. This information is relevant and there are scant data to be compared. Most of the studies use the numbers of unwanted pregnancies as proxy. $^{17-19}$

Most victims of violence were assaulted by unknown perpetrators $(67.2 \% ; 95 \% \mathrm{CI}=63.7-70.6 \%)$ in their residence (23.3\%; $95 \% \mathrm{CI}=20.4 \%-26.6 \%$ [ - Table 2]), which is in line with data presented by Delziovo et $\mathrm{al}^{20}$ in a sample of a public service in southern Brazil, in the state of Santa Catarina. Most victims of violence sought care within 72 hours after the occurrence $(80.7 \%$; 95\% CI $=77.7-83.5 \%$ (-Table 3 ). There was a low incidence of physical injuries in these victims (-Table 3). These findings are different from other authors, ${ }^{21}$ but they are in agreement with those found in a Danish cohort, where they reported a $2 \%$ incidence of physical injury. $^{22}$ The low incidence of physical injuries does not allow us to find a plausible explanation. Some authors explain it by the degree of resistance by the victim, ${ }^{23}$ while others explain this finding by the paralysis presented by the victim during the sexual assault. ${ }^{24}$ Both explanations seem valid but we are not able to perform such analysis.

Analysis of the ROC curve showed that abused women $<19$ years old had a 2.7 higher risk of not using any contraceptive method, compared with older women. This information is new and reveals the importance, for health professionals, to evaluate the contraceptive method used by the victim. Patel et $\mathrm{al}^{25}$ published that only $40 \%$ of emergency departments offer counseling and provision of emergency contraceptives.

After dividing the sample by the age of 19 years old, some significant differences were found, such as the type of sexual contact with the victims (-Tables 1 and $\mathbf{3}$ ). The majority of women $>19$ years old had a previous or current relationship, had $>10$ years of education and were employed. In contrast, most women $\leq 19$ years old were single, had $<9$ years of education and were students ( - Table $\mathbf{1}$ ). These findings are expected, since these social events, for example, to be married, are more frequent in older women. According to the literature, the younger the women who suffered sexual assault, the higher the incidence of psychologic and physical abnormalities in the future. ${ }^{26}$

The prevalence of known perpetrators was higher among women $\leq 19$ years old, compared with those $>19$ years old (-Table 2). This finding is in accordance with the data provided by Rapee, Abuse \& Incest (RAINN), an American anti-sexual violence organization (rainn.org). According to RAINN, $80 \%$ of the rapes are committed by someone known to the victim. ${ }^{27}$ Similar results were presented by Sodipo et $\mathrm{al}^{28}$ in Nigeria. Other authors have reported that rapists can be friends, colleagues or family members ${ }^{29,30}$ but they do not mention a difference in age. Possible explanations for this association can be related to cultural aspects of the community and the abusive behavior of the perpetrator, associated with the economic dependency of the victim. ${ }^{29}$ Further research is necessary on this topic.
The present study has some limitations. The sample is limited to one region in southern Brazil. A significant proportion of information, such as the location of the occurrence, the form of aggression, if ejaculation occurred, the age of the rapist and the form of violence (-Tables 2 and $\mathbf{3}$ ) were lacking, jeopardizing further analysis. Some variables, for instance, the age and number of rapists, were impossible to obtain from the history of the patient; many women were drugged or intoxicated and they were not able to recall the events. Others were traumatized and did not want to tell the details. However, although these variables were missing, others, from the same patient, were present, such as relationship with perpetrators and marital status, which had $99 \%$ of completeness. Thus, caution is required for interpreting our results on these variables.

A positive aspect of the present study is its 17-year span. This cohort presents data from the region of Porto Alegre, the city with the highest number of notifications in Rio Grande do Sul, according to the DATASUS. ${ }^{15}$ Efforts were made to minimize the inherent biases of this type of study, such as double-checking the data and active search with the patient in outpatient follow-up.

\section{Conclusion}

The victims of violence seen at the HCPA were mostly white, with a mean age of 24.4 years old. Those $<19$ years old had a higher RR: $2.7(95 \% \mathrm{CI}=1.96-3.6)$ of not using contraception, and the majority of the perpetrators are known by these young women. Health professionals must provide emergency contraception to these victims, mainly to those $<19$ years old. Emergency contraception is more effective before 72 hours and most victims seek care within 72 hours of the occurrence. Finally, the relationship with the perpetrator should be investigated and proper measures must be taken when the victim knows the perpetrator.

\section{Contributions}

All authors contributed to the writing of the article, relevant revision of the intellectual content and approved the final version submitted for publication.

Conflicts to Interests

The authors have no conflict of interests to declare.

Acknowledgments

To the Conselho Nacional de Desenvolvimento Científico e Tecnológico - CNPq. Grant: 302450/2018-1(RFS).

\section{References}

1 Krug EG, Dahlberg LL, Mercy JA, Zwi AB, Lozano R. World report on violence and health [Internet]. Geneva: World Health Organization; 2002 [cited 2019 Feb 10]. Available from: https://apps. who.int/iris/bitstream/handle/10665/42495/9241545615_eng. pdf? sequence $=1$

2 Abrahams N, Devries K, Watts C, Pallito C, Petzold M, Shamu S, García-Moreno C. Worldwide prevalence of non-partner sexual 
violence: a systematic review. Lancet. 2014;383(9929):1648-1654. Doi: 10.1016/S0140-6736(13)62243-6

3 Mondin TC, Cardoso TdeA, Jansen K, Konradt CE, Zaltron RF, Behenck MO, et al. Sexual violence, mood disorders and suicide risk: a population-based study. Cien Saude Colet. 2016;21(03): 853-860. Doi: 10.1590/1413-81232015213.10362015

4 World Health Organization, United Nations Office on Drugs and Crime, United Nations Development Programme. Global status report on violence prevention 2014 [Internet]. Geneva: World Health Organization; 2014 [cited 2018 Aug. 17]. Available from: https://www.who.int/violence_injury_prevention/violence/status_report/2014/en/

5 Winzer L. Frequency of self-reported sexual aggression and victimization in Brazil: a literature review. Cad Saude Publica. 2016;32(07):e00126315. Doi: 10.1590/0102-311X00126315

6 Delziovo CR, Bolsoni CC, Lindner SR, Coelho EBS. Quality of records on sexual violence against women in the Information System for Notifiable Diseases (Sinan) in Santa Catarina, Brazil, 2008-2013. Epidemiol Serv Saude. 2018;27(01):e20171493. Doi: 10.5123/ S1679-49742018000100003

7 Waiselfisz JJ. Mapa da violência 2015: homicídio de mulheres no Brasil. Brasília (DF): Flacso; 2015

8 Ministério da Saúde. DATASUS Tecnologia da Informação a Serviço do SUS. Violência doméstica, sexual e/ou outras violências Brasil [Internet]. 2018 [cited 2019 Feb 28]. Available from: http:// tabnet.datasus.gov.br/cgi/tabcgi.exe?sinannet/cnv/violebr.def

9 Facuri CdeO, Fernandes AMS, Oliveira KD, Andrade TdosS, Azevedo RCS. [Sexual violence: a descriptive study of rape victims and care in a university referral center in São Paulo State, Brazil]. Cad Saude Publica. 2013;29(05):889-898. Doi: 10.1590/S0102311X2013000500008

10 Sandalowski MC, Maia GF, Stuker P, Lock MP. Violência contra mulheres no Brasil e no Uruguai: as experiências da Lei Maria da Penha e da Lei de Violência Doméstica. Século XXI Rev Ciênc Soc. 2017;6(01):235-262. Doi: 10.5902/2236672525580

11 Patel A, Weber A, Piotrowskin H, Patel D. A national survey of emergency room provision of emergency contraception to sexual assault victims. Contraception. 2006;74(02):183. Doi: 10.1016/j. contraception.2006.05.018

12 Ministério da Saúde. Secretaria de Atenção à Saúde. Departamento de Ações Programáticas Estratégicas. [Prevention and treatment of insults resulting from sexual violence against women and adolescents: technical guidelines] [Internet]. 3a ed. Brasília (DF): Ministério da Saúde; 2012 [cited 2019 Jan 10]. Available from: https://bvsms.saude.gov.br/bvs/publicacoes/prevencao_agravo_violencia_sexual_mulheres_3ed.pdf

13 Majeed-Ariss R, Walker T, Lee P, White C. The experiences of sexually assaulted people attending Saint Mary's Sexual Assault Referral Centre for a forensic medical examination. J Forensic Leg Med. 2019;66:33-37. Doi: 10.1016/j.jflm.2019.06.001

14 Instituto Brasileiro de Geografia e Estatística. Distribuição da população por sexo, segundo os grupos de idade: Porto Alegre (RS) [Internet]. 2010 [cited 2019 Nov 19]. Available from: https:// censo2010.ibge.gov.br/sinopse/webservice/frm_piramide.php? codigo $=431490$ \& corhomem $=3 \mathrm{~d} 4590$ \& cormulher $=9 \mathrm{cdbfc}$

15 Ministério da Saúde. DATASUS Tecnologia da Informação a Serviço do SUS. Violência doméstica, sexual e/ou outras violências - Brasil: Rio Grande do Sul [Internet]. 2017 [cited 2020 Jun 29]. Available from: http://tabnet.datasus.gov.br/cgi/tabcgi.exe?sinannet/cnv/violebr.def
16 Instituto Brasileiro de Geografia e Estatística. Tabela 3175: População residente, por cor ou raça, segundo a situação do domicílio, o sexo e a idade [Internet]. 2010 [cited 2019 Nov 14]. Available from: https://sidra.ibge.gov.br/Tabela/3175\#resultado

17 Acharya K, Paudel YR, Silwal P. Sexual violence as a predictor of unintended pregnancy among married young women: evidence from the 2016 Nepal demographic and health survey. BMC Pregnancy Childbirth. 2019;19(01):196. Doi: 10.1186/s12884-019-2342-3

18 Gomez AM. Sexual violence as a predictor of unintended pregnancy, contraceptive use, and unmet need among female youth in Colombia. J Womens Health (Larchmt). 2011;20(09):1349-1356. Doi: $10.1089 /$ jwh.2010.2518

19 Dessalegn S, Kumbi S, Surur F. Sexual violence and use of contraception among women with unwanted pregnancy in an Ngo Clinic, Addis Ababa. Ethiop Med J. 2008;46(04):325-333

20 Delziovo CR, Bolsoni CC, Nazário NO, Coelho EBS. [Characteristics of sexual violence against adolescent and adult women reported by the public health services in Santa Catarina State, Brazil]. Cad Saude Publica. 2017;33(06):e00002716. Doi: 10.1590/0102$311 \times 00002716$

21 Sugar NF, Fine DN, Eckert LO. Physical injury after sexual assault: findings of a large case series. Am J Obstet Gynecol. 2004;190(01): 71-76. Doi: 10.1016/s0002-9378(03)00912-8

22 Larsen ML, Hilden M, Lidegaard Ø. Sexual assault: a descriptive study of 2500 female victims over a 10 -year period. BJOG. 2015; 122(04):577-584. Doi: 10.1111/1471-0528.13093

23 Turchik JA, Probst DR, Chau M, Nigoff A, Gidycz CA. Factors predicting the type of tactics used to resist sexual assault: a prospective study of college women. J Consult Clin Psychol. 2007; 75(04):605-614. Doi: 10.1037/0022-006x.75.4.605

24 Gidycz CA, Van Wynsberghe A, Edwards KM. Prediction of women's utilization of resistance strategies in a sexual assault situation: a prospective study. J Interpers Violence. 2008;23(05): 571-588. Doi: $10.1177 / 0886260507313531$

25 Patel A, Panchal H, Piotrowski ZH, Patel D. Comprehensive medical care for victims of sexual assault: a survey of Illinois hospital emergency departments. Contraception. 2008;77(06):426-430. Doi: 10.1016/j.contraception.2008.01.018

26 Trickett PK, Noll JG, Putnam FW. The impact of sexual abuse on female development: lessons from a multigenerational, longitudinal research study. Dev Psychopathol. 2011;23(02):453-476. Doi: $10.1017 /$ S0954579411000174

27 Perpetrators of sexual violence: statistics [Internet]. 2020 [cited 2020 Mar 5]. Available from: https://www.rainn.org/statistics/ perpetrators-sexual-violence

28 Sodipo OO, Adedokun A, Adejumo AO, Olibamoyo O. The pattern and characteristics of sexual assault perpetrators and survivors managed at a sexual assault referral centre in Lagos. Afr J Prim Health Care Fam Med. 2018;10(01):e1-e5. Doi: 10.4102/phcfm. v10i1.1727

29 Taylor LR, Gaskin-Laniyan N. Sexual assault in abusive relationships [Internet]. 2007 [cited 2020 Apr 6]. Available from: https://nij.ojp. gov/topics/articles/sexual-assault-abusive-relationships\#citation-1

30 Clark H, Quadara A. Insights into sexual assault perpetration, giving voice to victim/survivors' knowledge [Internet]. Melbourne: Australian Institute of Family Studies; 2010 [cited 2020 Mar 5]. Available from: https://aifs.gov.au/sites/default/files/publication-documents/rr18.pdf 